\title{
Poplar (Populus spp) growth and crop yields in a silvoarable experiment at three lowland sites in England
}

\author{
P. J. Burgess 1 , L. D. Incoll 2 , D. T. Corry ${ }^{2}$, A. Beaton ${ }^{3}$, \& B. J. Hart 4 \\ ${ }^{1}$ Cranfield University, Silsoe, Bedford MK45 4DT, UK; \\ 2 School of Biology, University of Leeds, Leeds LS2 9JT, UK; \\ 3 Pot Common, Red House Lane, Elstead, Surrey GU8 6DS, UK; \\ ${ }^{4}$ Royal Agricultural College, Cirencester GL7 6JS, UK
}

Author for correspondence:

Dr P. J. Burgess, Cranfield University, Silsoe, Bedford, MK45 4DT, U.K

Telephone number: $\quad+44-(0) 1525-863046$

Facsimile number: $\quad+44-(0) 1525-863344$

E-mail address: $\quad$ p.burgess@cranfield.ac.uk

Key words: Crop rotations, fallow, hybrids, Melampsora larici-populina, timber volume, tree-crop interaction.

\begin{abstract}
In early 1992, a silvoarable experiment, comprising four poplar (Populus spp.) hybrids (at a spacing of $10 \mathrm{~m} \times 6.4 \mathrm{~m}$ ) and four arable treatments, was established at three contrasting lowland sites in England. By the end of 1998, seven years after planting, the height of the poplar hybrid Beaupre $(11.9 \mathrm{~m})$ was greater than those of the hybrids Gibecq, Robusta and Trichobel (8.9-9.8 m). The trees at the most exposed site had the shortest height $(9.2 \mathrm{~m})$ and the greatest diameter at breast height $(173 \mathrm{~mm})$. Tree growth was also affected by the arable treatments. The height $(9.5 \mathrm{~m})$ and diameter $(143 \mathrm{~mm})$ of the trees bordered on both sides by a continuous rotation of arable crops were $89 \%$ and $79 \%$, respectively, of those bordered on both sides by a regularly cultivated fallow. This result could be explained by competition for water. Across the three sites, in the presence of the trees the yield per unit cropped area, relative to that in the control areas, was an average of $4 \%$ less in the first three years and an average of $10 \%$ less between years four and six. However the specific responses were dependent on the arable crop. The experiment also included an alternately-cropped arable treatment, where the crop was alternated with a one-year bare fallow. The benefits of a preceding fallow, rather than a cereal crop, for yield were greatest for wheat (Triticum aestivum L.) and barley (Hordeum vulgare L.) and least for field beans (Vicia faba L.), peas (Pisum sativum L.) and mustard (Brassica alba L.).
\end{abstract}




\section{Introduction}

Two objectives of European and British agricultural policy are the reduction of agricultural surpluses and increased tree planting on farms. However tree planting on farms in lowland Britain has often seemed unattractive because of the time required to produce marketable timber. To some extent, this constraint has been reduced by the introduction of fastgrowing hybrid clones of poplar (Populus spp) from Belgium that are able to produce a harvestable timber crop in 25 years (Potter et al., 1990; Tabbush, 1995).

A second constraint to the planting of trees is the negative cash flow between planting and harvest. However, because poplars are sometimes planted at low density (156 trees ha${ }^{1}$ ) and left unthinned throughout the rotation (Beaton, 1987; Tabbush, 1995), one method of maintaining a positive cash flow in the initial years, in the absence of government subsidies, is to grow an arable crop between the trees - a practice known in Europe as silvoarable agroforestry. Such a practice was successfully implemented by Bryant and May (Forestry) Ltd on their estates in East Anglia and Herefordshire, UK during the 1960s and 1970s (Jobling, 1990). Financial analyses have also predicted that agroforestry with the new hybrids of poplar could again be viable on good arable land in the UK (Willis et al., 1993).

However the predicted profitability of a silvoarable practice depends on the actual interaction between tree growth and crop yield. In 1992, a silvoarable experiment with poplar was established at a national network of three lowland sites in England to investigate the effect of the interaction on profitability. This paper describes the experiment and reports some of the measurements of tree growth and crop yield during the first seven years.

\section{Materials and methods}

\section{Sites and climate}

The sites are in three of the major arable areas in lowland England (Table 1). The wettest and most westerly site is on the Royal Agricultural College Farm at Fosse Hill near Cirencester in Gloucestershire (lat. $51^{\circ} 44^{\prime} \mathrm{N}$, long. $2^{\circ} 0^{\prime} \mathrm{W}$ ). The coolest and most northerly site is on the Leeds University Farms near Tadcaster in West Yorkshire (lat. 53 $53^{\circ} \mathrm{N}$, long. $1^{\circ} 15^{\prime} \mathrm{W}$ ); the warmest and driest site is at Silsoe in Bedfordshire (lat. $52^{\circ} 0^{\prime} \mathrm{N}$, long. $0^{\circ} 26^{\prime} \mathrm{W}$ ) in eastern England. The soil textures at the Cirencester, Leeds and Silsoe sites are clay loam over limestone, sandy clay loam over limestone, and clay over clay respectively.

\section{Poplar hybrids}

Four poplar hybrids were chosen to represent the major groups of poplars being grown in Britain. Trichobel is an intraspecific hybrid of black cottonwood (Populus trichocarpa Torrey \& A. Gray ex Hook.), a species originally from western North America. Gibecq is a 'euramericana' hybrid produced by crossing eastern cottonwood from eastern North America (Populus deltoides Bartram ex Marshall) with European native black poplar (Populus nigra L.). Beaupré is an 'interamericana' hybrid, produced by crossing the two cottonwood species from North America. Trichobel, Gibecq and Beaupré were bred at the Poplar Research Centre at Geraardsbergen, Belgium in the 1960s, and imported into the 
UK in 1985 (Jobling, 1990). Robusta is a natural 'euramericana' hybrid originally selected in the 1890s in the north-east of France (Jobling, 1990).

Table 1. The characteristics of the three lowland sites in England.

\begin{tabular}{lccc}
\hline & \multicolumn{3}{c}{ Site } \\
\cline { 2 - 4 } Characteristic & Cirencester & Leeds & Silsoe \\
\hline Altitude $(\mathrm{m})$ & 130 & 50 & 60 \\
Annual rainfall $(\mathrm{mm})$ & 800 & 634 & 629 \\
Mean air temperature $\left({ }^{\circ} \mathrm{C}\right)$ & 9.7 & 9.3 & 10.0 \\
Daily wind run $(\mathrm{km})$ & $\mathrm{n} / \mathrm{a}$ & 238 & 150 \\
Slope & 'Gentle' & 'Gentle' & Flat \\
Aspect & South-east & West-north-west & None \\
Topsoil depth $(\mathrm{m})$ & $>0.5$ & 0.5 & $>0.5$ \\
Soil description & Clay loam & Sandy clay loam & Clay \\
& over limestone & over limestone & over clay \\
\hline
\end{tabular}

${ }^{1}$ Rainfall, temperature and daily wind run are the means of the annual values from 1992 to 1998.

\section{Experimental design}

At each site, the main experiment covers 2.5 ha and comprises three replicate blocks that include each combination of the four poplar hybrids and three of four arable treatments (Fig. 1). The poplar hybrids were planted between March and April 1992 as 1.5-2.0 m unrooted sets to a depth of $0.6 \mathrm{~m}$, at intervals of $6.4 \mathrm{~m}$ in a North-South direction in rows $10 \mathrm{~m}$ apart, along parallel lengths of $1.5-\mathrm{m}$-wide black polythene-film mulch. The edges of the plastic were buried under the soil mechanically to leave an exposed strip of plastic 1-mwide. Along each row, the four hybrids were planted as contiguous groups of five trees, with a guard tree (buffer) at each end of each row.

Each autumn, an 8-m-wide strip was ploughed, in the middle of each 10-m-wide alley, leaving the tree row as an uncultivated 2-m-wide strip, including the polythene mulch. This deep cultivation broke any poplar roots in the top $20 \mathrm{~cm}$ of the arable area. Within each block, six alleys were allocated in adjacent pairs to three arable treatments designated as 'continuously-fallow', 'continuously-cropped' and 'alternately-cropped'. Hence every second row of poplars, termed a 'measurement' row (M, Fig. 1), was subjected to one of three arable treatments. The two adjacent alleys comprising the continuously-fallow treatment were regularly cultivated so that the measurement row of poplars between them would have minimal competition from crops or weeds. The continuously-cropped treatment comprised a rotation of two to four years of cereals in two adjacent alleys followed by a break (non-cereal) crop. In the alternately-cropped treatment, the alley on one side of the measurement row of trees was cropped whilst the alley on the opposite side was kept fallow; the cropped and the fallow areas were reversed each year. 


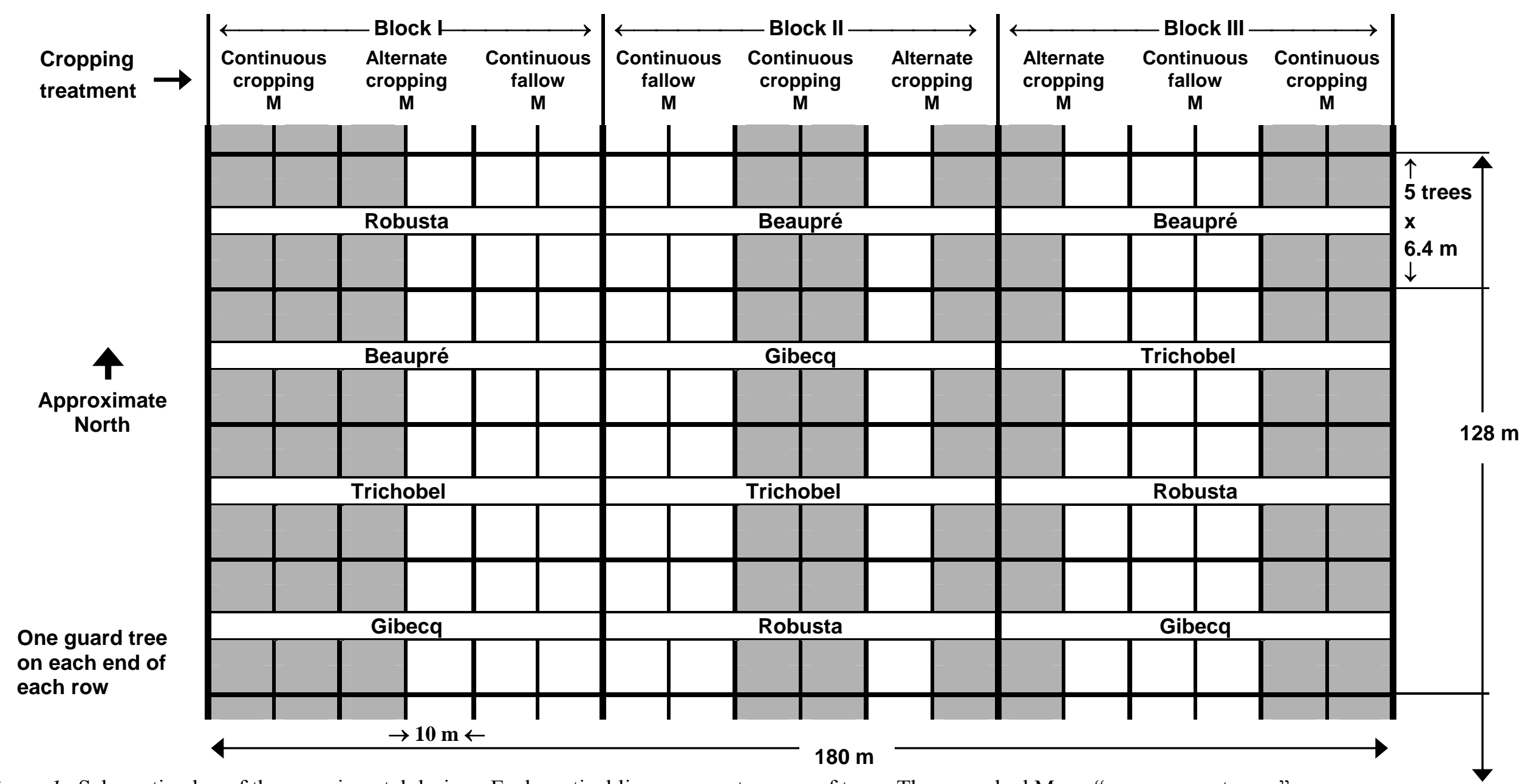

Figure 1. Schematic plan of the experimental design. Each vertical line represents a row of trees. Those marked M are "measurement rows".

Unshaded alleys are either permanent fallow or fallow alternating with crop; shaded alleys are either permanently cropped or crop alternating with

fallow. The hybrid name of each of the four sets of trees randomised in each block is designated by a banner across the set. 
In the experiment, the crops are termed either 'winter' (if planted between September and November so that they are in the ground during the winter) or 'spring' (if planted in March or April). In each case, the crops were harvested between the following July and September and hence only one crop was harvested each year. Starting in 1992, the rotation at Cirencester comprised three crops of barley (Hordeum vulgare L.), field beans (Vicia faba L.), wheat (Triticum aestivum L.), barley, and field beans. Also starting in 1992, the rotation at Leeds comprised barley, peas (Pisum sativum L.), two crops of wheat, barley, mustard (Brassica alba L.), and wheat. At Silsoe, following poor crop yields in the initial three years, a wheat crop was harvested in 1995, followed by two wheat crops and field beans.

The cropped areas were managed in the same way as commercial crops, receiving standard applications of fertiliser, herbicides, fungicides and insecticides as appropriate. At Leeds and Cirencester the mid-point of the tractor tramlines was offset $6 \mathrm{~m}$ from the edge of the measurement tree row; at Silsoe it was centred in the alley $4 \mathrm{~m}$ from the edge of the tree row. Lastly the fourth arable treatment, a 'control area' adjacent to the main experiment, but at least $15 \mathrm{~m}$ from the base of the nearest poplar, was managed in the same way as the continuously-cropped treatment.

\section{Measurements and analysis of data}

From 1992, the height of each tree in the measurement row of each arable treatment was measured each winter between November and March. From 1994 at Cirencester and Leeds, and from 1995 at Silsoe, the diameters of the same trees were measured at breast height (1.3 $\mathrm{m}$ above the ground) each winter.

Each year, the grain, bean or pea yield, within each poplar-hybrid $\mathrm{x}$ arable-treatment plot was determined by harvesting with a plot combine at three distances from the trees in the measurement row. The approximate distances were: 1.0-2.5 m, 2.5-4.0 m and 4.0-5.5 $\mathrm{m}$ giving three sub-plots in each alternately-cropped treatment and six sub-plots in each continuously-cropped treatment. Corresponding measurements were also taken within the control area; within a specific year the number of replicates ranged from 1 to 24 at Cirencester and from 12 to 27 at Silsoe. A consistent 24 measurements of control yield were taken each year at Leeds. The dry matter yield of the spring mustard 'cover' crop, at Leeds in 1997, was determined by measuring the total yield of fresh mass of the aboveground part of each sub-plot of the crop and taking sub-samples for dry matter determination.

The crop yield data were analysed by ANOVA (SAS) in a split/split plot design. Because there were only three replicate cropped alleys in the alternately-cropped treatment, the design was not balanced in terms of the number of replicates with a westerly or an easterly aspect relative to the measurement row of trees. Therefore each year the yields from the continuously-cropped treatment were analysed first to determine the effect of the west-east aspect. If there was no effect of aspect then the whole experiment (continuouslyand alternately-cropped treatments) was analysed as one set to determine the effect of the arable treatment. If there was an effect of aspect (as at Cirencester in 1993, at Leeds in 1995, 1996, 1997 and 1998, and at Silsoe in 1998) then in the comparison of continuouslycropped and alternately-cropped treatments only those continuous plots which had the same aspect as the alternate plots were included in the analysis. The control crop data were analysed by a two-way ANOVA and compared with the other treatments by t-test at $\mathrm{P}=$ 0.05 . 
In order to assess shading by the trees, total short-wave solar radiation was measured beneath three Trichobel trees at the Silsoe site at monthly intervals between 24 April and 24 July 1997. At this time, the mean height of the three trees was $7.6 \mathrm{~m}$, the mean canopy depth was $5.0 \mathrm{~m}$, and the mean maximum canopy diameter was $3.9 \mathrm{~m}$. Below each tree, five tube solarimeters which had been calibrated against a standard Kipp solarimeter, were placed along a 10-m transect centred on the tree and perpendicular to the tree-row. A sixth solarimeter was placed outside the experiment where there was no significant shading.

\section{Silvoarable management}

The successful management of a silvoarable practice requires two additional activities not usually associated with traditional forestry or agriculture. First, in order to produce the maximum volume of high quality knot-free timber, the branches of the poplar were pruned before they reached a diameter of $5 \mathrm{~cm}$ (Jobling, 1990). The lowest branches were removed during the first year after planting, and subsequently whorls were removed during the second, fourth, sixth and seventh year. The trees at Cirencester and Silsoe were pruned between harvest and autumn cultivation. After 1995, the trees at Leeds were pruned during the winter. Second, it was necessary to manage the understorey vegetation in the tree row between the edge of the black plastic mulch and the crop i.e. in two strips $50-\mathrm{cm}$ wide. At Leeds and Cirencester, this vegetation was controlled as required by herbicide (glyphosate) applied from a knapsack sprayer. At Silsoe, the vegetation was controlled with a hand-held petrol-driven strim-mower.

\section{RESULTS}

\section{Establishment of trees}

During the first year, the proportion of sets in the measurement rows, which did not establish, ranged from $9-10 \%$ at Silsoe and Cirencester to $34 \%$ at Leeds (Table 2). Across the three sites, the losses ranged from 4\% for Beaupré to 37\% for Robusta. The loss over all hybrids in the year of establishment was $18 \%$. The particularly poor establishment of two hybrids at Leeds may have been linked to the greater exposure of the site to wind and the relatively shallow topsoil (Table 1). Although the dead trees were replaced with healthy transplants at the end of the first season, the differences in the proportions replaced would have affected subsequent height and diameter measurements.

Table 2. Proportion (\%) of the 45 trees of each hybrid lost from the measurement rows at each of three lowland sites in England during the year of establishment.

\begin{tabular}{lcccc}
\hline & \multicolumn{3}{c}{ Site } & Mean \\
\cline { 2 - 4 } Hybrid & Cirencester & Leeds & Silsoe & 4 \\
\hline Beaupré & 7 & 4 & 2 & 12 \\
Trichobel & 7 & 7 & 22 & 37 \\
Robusta & 20 & 73 & 18 & 19 \\
Gibecq & 2 & 53 & 0 & \\
\hline Mean & 9 & 34 & 10 & \\
\hline
\end{tabular}

\section{Height and diameter of trees}


At the end of 1998, seven years after planting, there were significant effects of site, hybrid, and arable treatment on height $(\mathrm{P}<0.01)$ and diameter $(\mathrm{P}<0.01)$. Although there was no significant $(\mathrm{P}<0.05)$ interaction between hybrid and arable treatment, there were interactions between hybrid and site on height $(\mathrm{P}<0.05)$ and diameter $(\mathrm{P}<0.05)$.

The main effect of site was that the height of the trees at Cirencester and Silsoe $(10.4 \mathrm{~m})$ was greater $(\mathrm{P}<0.01)$ than that at Leeds $(9.2 \mathrm{~m})$ (Table 3$)$. In contrast the diameters of the trees at Cirencester and Silsoe $(156$ and $155 \mathrm{~mm})$ were less $(\mathrm{P}<0.01)$ than that at Leeds (173 $\mathrm{mm})$.

The main effect of hybrid across the sites was that the height of Beaupré $(11.9 \mathrm{~m})$ was $21-34 \%$ greater than those for the other three hybrids $(8.9-9.8 \mathrm{~m})$. Likewise, the diameter of Beaupré (189 $\mathrm{mm}$ ) was $18-28 \%$ greater than the diameters of the other three hybrids (148-160 mm). At each of the three sites, the heights of Trichobel and Robusta were similar. A significant site $\mathrm{x}$ hybrid (tree) interaction was that the diameter of Gibecq was less $(\mathrm{P}<0.05)$ than that of Trichobel at Cirencester, the opposite of that at Silsoe. The relatively poor growth of Trichobel at Silsoe is probably, in part, a result of the poor establishment of this hybrid at Silsoe in the year of planting (Table 2).

Table 3. Height and diameter at breast height (dbh) of each of four poplar hybrids at each of three lowland sites in England at the end of the seventh growing season after planting.

\begin{tabular}{|c|c|c|c|c|c|c|}
\hline \multirow[b]{2}{*}{ Property } & \multirow[b]{2}{*}{ Hybrid } & \multicolumn{3}{|c|}{ Site } & \multirow{2}{*}{\multicolumn{2}{|c|}{ Mean }} \\
\hline & & Cirencester & Leeds & Silsoe & & \\
\hline \multirow[t]{5}{*}{ Height (m) } & Beaupré & $12.5 \mathrm{a}$ & $11.2 \mathrm{a}$ & $12.1 \mathrm{a}$ & 11.9 & \\
\hline & Trichobel & $10.4 \mathrm{~b}$ & $9.3 \mathrm{~b}$ & $9.6 \mathrm{~b}$ & 9.8 & \\
\hline & Robusta & $9.8 \mathrm{bc}$ & $8.8 \mathrm{~b}$ & $9.7 \mathrm{~b}$ & 9.4 & bc \\
\hline & Gibecq & $9.1 \mathrm{c}$ & $7.7 \mathrm{c}$ & $10.0 \mathrm{~b}$ & 8.9 & \\
\hline & Mean & 10.4 & 9.2 & 10.4 & & \\
\hline \multirow[t]{5}{*}{$\mathrm{Dbh}(\mathrm{mm})$} & Beaupré & $184 \quad \mathrm{a}$ & $199 \quad \mathrm{a}$ & $184 \mathrm{a}$ & 189 & $\mathrm{a}$ \\
\hline & Trichobel & $163 \mathrm{~b}$ & $175 \quad b$ & $141 \mathrm{c}$ & 160 & $\mathrm{~b}$ \\
\hline & Robusta & $141 \mathrm{c}$ & $162 \mathrm{~b}$ & $142 \mathrm{c}$ & 148 & $\mathrm{c}$ \\
\hline & Gibecq & $139 \mathrm{c}$ & $157 \quad b$ & $154 \quad \mathrm{~b}$ & 150 & $\mathrm{c}$ \\
\hline & Mean & 156 & 173 & 155 & & \\
\hline
\end{tabular}

Values followed by the same letter are not significantly different for that site at $\mathrm{P}=0.05(\mathrm{n}=41-45$, except for Robusta at Leeds $(n=30)$; where trees are less than 45 in a set, some trees have died or are evidently of a different cultivar).

\section{Effects of arable treatment on tree growth}

In December 1998, seven years after planting, the heights of the trees in the continuouslycropped treatment at each site (8.8-9.9 m) were only $89-91 \%$ of those in the continuouslyfallow treatment (9.7-11.1 m) (Table 4). An even greater difference was apparent in the measurements of diameter. The diameters of the poplars in the continuously-cropped treatment (133-156 mm) were only $75-83 \%$ of those in the continuously-fallow treatment $(174-188 \mathrm{~mm})$. The heights and diameters in the alternately-cropped treatment were intermediate in value. 
Table 4. Effect of arable treatment on height and diameter at breast height (dbh) of poplar hybrids at each of three lowland sites in England at the end of the seventh growing season after planting.

\begin{tabular}{|c|c|c|c|c|c|}
\hline \multirow[b]{2}{*}{ Property } & \multirow[b]{2}{*}{ Arable treatment } & \multicolumn{3}{|c|}{ Site } & \multirow[b]{2}{*}{ Mean } \\
\hline & & Cirencester & Leeds & Silsoe & \\
\hline \multirow[t]{3}{*}{ Height (m) } & Continuously-fallow & $11.0 \mathrm{a}$ & $9.7 \mathrm{a}$ & $11.1 \mathrm{a}$ & $10.6 \mathrm{a}$ \\
\hline & Alternately-cropped & $10.6 \mathrm{ab}$ & $9.2 \mathrm{a}$ & $10.1 \mathrm{~b}$ & $10.0 \mathrm{~b}$ \\
\hline & Continuously-cropped & $9.8 \mathrm{~b}$ & $8.8 \mathrm{a}$ & $9.9 \mathrm{~b}$ & $9.5 \mathrm{c}$ \\
\hline \multirow[t]{3}{*}{ Dbh (mm) } & Continuously-fallow & 178 & 188 & $174 \quad \mathrm{a}$ & 180 \\
\hline & Alternately-cropped & $158 \quad b$ & 176 & 151 & 162 \\
\hline & Continuously-cropped & $133 \mathrm{c}$ & 156 & $140 \mathrm{c}$ & 143 \\
\hline
\end{tabular}

Values followed by the same letter are not significantly different for that site at $\mathrm{P}=0.05(\mathrm{n}=50-60$ for Cirencester and Leeds sites, and $n=60$ for the Silsoe site). Where $n \neq 60$ in a set, some trees have died or are evidently of a different cultivar).

The heights and diameters described in Table 4 are the cumulative effect of seven years of growth. However the effect of the arable treatment on the annual increase in height varied with year, and in 1994 and 1997 there were significant $(\mathrm{P}<0.05)$ site $\mathrm{x}$ arable treatment interactions. In the second season after planting (1993), which was particularly wet between April and August, at each site the increases in tree height were similar in the three arable treatments (Table 5). During the third season (1994) at Cirencester and the third and fourth seasons (1994 and 1995) at Leeds, the increase in tree height in the continuously-fallow treatment was greater $(\mathrm{P}<0.05)$ than that in the continuously-cropped treatment. After this, the effect of arable treatment on the increase in tree height was not significant. By contrast at Silsoe, which was often the driest site, the arable treatments had a significant effect on the annual increase in tree height during the third, fourth, fifth, sixth and seventh seasons (1994-1998) after planting. For each of the last four seasons, the increase in tree height in the continuously-fallow treatment was greater $(\mathrm{P}<0.05)$ than that in the continuously-cropped treatment (Table 5).

Table 5. Effect of arable treatment on the increase in height (m) at each of three lowland sites in England for each of six growing seasons, together with the corresponding April to August rainfall $(\mathrm{mm})$

\begin{tabular}{llcccccc}
\hline & & \multicolumn{5}{c}{ Growing season (year) } \\
\cline { 2 - 8 } Site & Treatment and rainfall & 1993 & 1994 & 1995 & 1996 & 1997 & 1998 \\
\hline Cirencester & Continuously-fallow & $1.25 \mathrm{a}$ & $1.17 \mathrm{a}$ & $1.96 \mathrm{a}$ & $1.47 \mathrm{a}$ & $1.93 \mathrm{a}$ & $1.50 \mathrm{a}$ \\
& Alternately-cropped & $1.35 \mathrm{a}$ & $1.12 \mathrm{ab}$ & $1.50 \mathrm{a}$ & $1.44 \mathrm{a}$ & $1.91 \mathrm{a}$ & $1.33 \mathrm{a}$ \\
& Continuously-cropped & $1.27 \mathrm{a}$ & $0.99 \mathrm{a}$ & $1.30 \mathrm{a}$ & $1.45 \mathrm{a}$ & $1.81 \mathrm{a}$ & $1.45 \mathrm{a}$ \\
\cline { 2 - 9 } & Rainfall & 361 & 245 & 106 & 220 & 331 & 291 \\
\hline \multirow{2}{*}{ Leeds } & Continuously-fallow & $1.17 \mathrm{a}$ & $1.15 \mathrm{a}$ & $1.64 \mathrm{a}$ & $1.36 \mathrm{a}$ & $1.88 \mathrm{a}$ & $1.35 \mathrm{a}$ \\
& Alternately-cropped & $1.14 \mathrm{a}$ & $1.12 \mathrm{a}$ & $1.23 \mathrm{~b}$ & $1.32 \mathrm{a}$ & $1.81 \mathrm{a}$ & $1.38 \mathrm{a}$ \\
& Continuously-cropped & $1.05 \mathrm{a}$ & $0.95 \mathrm{~b}$ & $0.99 \mathrm{c}$ & $1.35 \mathrm{a}$ & $1.69 \mathrm{a}$ & $1.28 \mathrm{a}$ \\
\cline { 2 - 9 } & Rainfall & 286 & 206 & 102 & 207 & 394 & 331 \\
\hline \multirow{2}{*}{ Silsoe } & Continuously-fallow & $1.22 \mathrm{a}$ & $0.99 \mathrm{~b}$ & $1.82 \mathrm{a}$ & $1.67 \mathrm{a}$ & $2.05 \mathrm{a}$ & $1.71 \mathrm{a}$ \\
& Alternately-cropped & $1.26 \mathrm{a}$ & $0.99 \mathrm{~b}$ & $1.65 \mathrm{~b}$ & $1.33 \mathrm{~b}$ & 1.75 & $1.59 \mathrm{ab}$ \\
& & & & & & $\mathrm{b}$ & $1.41 \mathrm{c}$ \\
& Continuously-cropped & $1.37 \mathrm{a}$ & $1.19 \mathrm{a}$ & $1.25 \mathrm{c}$ & $1.41 \mathrm{~b}$ & $1.47 \mathrm{~b}$ \\
\cline { 2 - 8 } & Rainfall & 334 & 194 & 92 & 157 & 224 & 294 \\
\hline
\end{tabular}

Values followed by the same letter are not significantly different for that year at $\mathrm{P}=0.05(\mathrm{n}=12$ to 60). 1998 was the seventh growing season after planting. 
In contrast to the height increment, the effect of the arable treatments on the diameter increment was more consistent from year to year and across sites (Table 6). In four out of five years at Cirencester and Leeds, and in four out of four years at Silsoe, the diameter increment of the trees in the continuously-fallow treatment was greater $(\mathrm{P}<0.05)$ than that in the continuously-cropped treatment. At Leeds, the only year where there was no significant effect of the arable treatment on diameter increment was 1997, which was also the year with the greatest April to August rainfall.

Table 6. Effect of arable treatment on the increase in the diameter at breast height $(\mathrm{mm})$ at each of three lowland sites in England for each of five growing seasons, together with the corresponding April to August rainfall (mm).

\begin{tabular}{llrrrrrr}
\hline & & \multicolumn{7}{c}{ Growing season (year) } \\
\cline { 2 - 8 } Site & Treatment and rainfall & 1994 & 1995 & 1996 & 1997 & 1998 \\
\hline Cirencester & Continuously-fallow & $21 \mathrm{a}$ & $35 \mathrm{a}$ & $36 \mathrm{a}$ & $34 \mathrm{a}$ & $19 \mathrm{a}$ \\
& Alternately-cropped & $21 \mathrm{a}$ & $27 \mathrm{~b}$ & $27 \mathrm{~b}$ & $31 \mathrm{~b}$ & $17 \mathrm{~b}$ \\
& Continuously-cropped & $17 \mathrm{a}$ & $22 \mathrm{c}$ & $25 \mathrm{c}$ & $27 \mathrm{c}$ & $16 \mathrm{~b}$ \\
\cline { 2 - 9 } & Rainfall & 245 & 106 & 220 & 331 & 291 \\
\hline \multirow{2}{*}{ Leeds } & Continuously-fallow & $27 \mathrm{a}$ & $38 \mathrm{a}$ & $33 \mathrm{a}$ & $34 \mathrm{a}$ & $39 \mathrm{a}$ \\
& Alternately-cropped & $25 \mathrm{a}$ & $30 \mathrm{~b}$ & $29 \mathrm{~b}$ & $35 \mathrm{a}$ & $39 \mathrm{a}$ \\
& Continuously-cropped & $20 \mathrm{~b}$ & $21 \mathrm{c}$ & $25 \mathrm{c}$ & $33 \mathrm{a}$ & $36 \mathrm{~b}$ \\
\hline \multirow{2}{*}{ Silsoe } & Rainfall & 206 & 102 & 207 & 394 & 331 \\
& Continuously-fallow & $\mathrm{n} / \mathrm{a}$ & $33 \mathrm{a}$ & $34 \mathrm{a}$ & $36 \mathrm{a}$ & $29 \mathrm{a}$ \\
& Alternately-cropped & $\mathrm{n} / \mathrm{a}$ & $30 \mathrm{~b}$ & $25 \mathrm{~b}$ & $29 \mathrm{~b}$ & $27 \mathrm{~b}$ \\
& Continuously-cropped & $\mathrm{n} / \mathrm{a}$ & $24 \mathrm{c}$ & $24 \mathrm{c}$ & $23 \mathrm{c}$ & $24 \mathrm{c}$ \\
\cline { 2 - 8 } & Rainfall & 194 & 92 & 157 & 224 & 294 \\
\hline
\end{tabular}

Values followed by the same letter are not significantly different for that year and site at $\mathrm{P}=0.05$ ( $\mathrm{n}=12$ to 60).

\section{Yields in the control area and continuously-cropped treatment}

Within the control areas at Cirencester and Leeds, the yields for winter wheat (8.2-10.1 $\left.\mathrm{t} \mathrm{ha}^{-1}\right)$, winter barley $\left(7.6-8.2 \mathrm{t} \mathrm{ha}^{-1}\right)$, spring barley $\left(5.2-7.7 \mathrm{tha}^{-1}\right)$ and peas $\left(5.5 \mathrm{t} \mathrm{ha}^{-1}\right)$ were similar to those achieved on other well-managed highly-productive farms (Nix, 1997) (Table 7). By contrast, due to management problems, the yields obtained at the Silsoe site between 1992 and 1994 were very low and therefore they are not presented. The control yields obtained from the winter wheat at Silsoe between 1995 and 1997 were acceptable (5.4-7.8 $\left.\mathrm{t} \mathrm{ha}^{-1}\right)$ but still relatively low.

In 1992, the year that the poplars were planted, the crop yields in the alleys at Cirencester and Leeds were greater than those in the control areas (Table 7). In contrast, between 1995 and 1998, when the trees were larger, the yields in the continuously-cropped treatment at Cirencester and Leeds were less than those in the control areas. At Silsoe, where the overall yields were lower, the first significant difference between the yields in the continuously-cropped treatment and the control area occurred in 1998. Overall during the first three years after planting, the yield in the continuously-cropped treatment at Cirencester and Leeds was $4 \%$ less than that in the corresponding control area. Between the fourth and the sixth years after planting, the yield reduction across the three sites was $10 \%$, and in the seventh year, the reduction at Leeds and Silsoe was $14 \%$. 
Table 7. Yields of the arable crops in the control area, the continuously- and alternately-cropped treatments in the silvoarable experiment at each of three lowland sites in England from 1992 to 1998, expressed in terms of the cropped area.

\begin{tabular}{|c|c|c|c|c|c|c|c|}
\hline \multirow[t]{3}{*}{ Site } & \multirow[t]{3}{*}{ Year } & \multirow[t]{3}{*}{ Crop } & \multicolumn{5}{|c|}{ Arable treatment } \\
\hline & & & \multirow{2}{*}{$\begin{array}{l}\text { Control } \\
\text { Yield } \\
\left(\mathrm{t} \mathrm{ha}^{-1}\right)\end{array}$} & \multicolumn{2}{|c|}{ Continuously-cropped } & \multicolumn{2}{|c|}{ Alternately-cropped } \\
\hline & & & & $\begin{array}{l}\text { Yield } \\
\left(\mathrm{t} \mathrm{ha}^{-1}\right)\end{array}$ & $\begin{array}{c}\text { Relative } \\
\text { yield } \\
(\%) \\
\end{array}$ & $\begin{array}{l}\text { Yield } \\
\left(\mathrm{t} \mathrm{ha}^{-1}\right) \\
\end{array}$ & $\begin{array}{c}\text { Relative } \\
\text { yield } \\
(\%)\end{array}$ \\
\hline \multirow[t]{7}{*}{ Cirencester } & 92 & Spring barley & $5.2 \mathrm{~b}^{1}$ & $5.5 \mathrm{a}$ & 106 & $5.5 \mathrm{ab}$ & 106 \\
\hline & 93 & Spring barley & $7.7^{2}$ & $6.8 \mathrm{~b}$ & 88 & $7.3 \mathrm{a}$ & 94 \\
\hline & 94 & Winter barley & $8.2 \mathrm{a}$ & $6.9 \mathrm{~b}$ & 83 & $8.4 \mathrm{a}$ & 102 \\
\hline & 95 & Winter beans & $2.8 \mathrm{a}$ & $2.0 \mathrm{~b}$ & 71 & $2.0 \mathrm{~b}$ & 71 \\
\hline & 96 & Winter wheat & $10.1 \mathrm{a}$ & $7.9 \mathrm{c}$ & 77 & $8.6 \mathrm{~b}$ & 85 \\
\hline & 97 & Winter barley & $7.6 \mathrm{a}$ & $6.5 \mathrm{~b}$ & 85 & $7.4 \mathrm{a}$ & 97 \\
\hline & 98 & Winter beans & \multicolumn{5}{|c|}{ Crop failure in all treatments } \\
\hline \multirow[t]{7}{*}{ Leeds } & 92 & Spring barley & $6.3 \mathrm{~b}$ & $6.6 \mathrm{a}$ & 104 & $6.6 \mathrm{a}$ & 105 \\
\hline & 93 & Spring peas & $5.5 \mathrm{a}$ & $4.8 \mathrm{~b}$ & 88 & $4.6 \mathrm{~b}$ & 84 \\
\hline & 94 & Winter wheat & $8.7 \mathrm{~b}$ & $9.2 \mathrm{a}$ & 106 & $8.4 \mathrm{~b}$ & 97 \\
\hline & 95 & Winter wheat & $8.2 \mathrm{~b}$ & $7.8 \mathrm{c}$ & 96 & $8.8 \mathrm{a}$ & 108 \\
\hline & 96 & Winter barley & $7.7 \mathrm{a}$ & $6.9 \mathrm{~b}$ & 90 & $7.0 \mathrm{~b}$ & 91 \\
\hline & 97 & Spring mustard & $4.2 \mathrm{a}$ & $3.6 \mathrm{~b}$ & 85 & $3.3 \mathrm{c}$ & 80 \\
\hline & 98 & Winter wheat & $10.6 \mathrm{a}$ & $9.6 \mathrm{~b}$ & 91 & $8.2 \mathrm{c}$ & 77 \\
\hline \multirow[t]{5}{*}{ Silsoe } & 94 & Spring wheat & & & Low yields & & \\
\hline & 95 & Winter wheat & $7.8 \mathrm{~b}$ & $8.1 \mathrm{~b}$ & 104 & $8.6 \mathrm{a}$ & 110 \\
\hline & 96 & Winter wheat & $7.5 \mathrm{~b}$ & $7.3 \mathrm{~b}$ & 98 & $9.1 \mathrm{a}$ & 121 \\
\hline & 97 & Winter wheat & $5.5 \mathrm{a}$ & $5.6 \mathrm{a}$ & 104 & $5.8 \mathrm{a}$ & 108 \\
\hline & 98 & Winter beans & $4.4 \mathrm{a}$ & $3.6 \mathrm{~b}$ & 82 & $3.3 \mathrm{c}$ & 76 \\
\hline
\end{tabular}

${ }^{1}$ Values followed by the same letter for each year and site (i.e. each row of the table) are not significantly different at $\mathrm{P}=0.05$. $^{2}$ In 1993 at Cirencester, only a single measurement of the control yield was made. Relative yields are expressed as a proportion of the control.

\section{Yields in the alternately-cropped treatment}

There were eight occasions (three years at Cirencester, two years at Leeds and three years at Silsoe) when a cereal crop was preceded by another cereal in the continuously-cropped treatment (Table 7). On two of these occasions there was no significant difference in the yields between the continuously- and alternately-cropped treatments (in 1996 at Leeds and in 1997 at Silsoe). However on six of the eight occasions (in 1993, 1994 and 1997 at Cirencester; in 1995 at Leeds, and in 1995 and 1996 at Silsoe), the yield in the alternatelycropped treatment was significantly $(\mathrm{P}<0.05)$ greater than that in the continuously-cropped treatment. The increase in yield across the eight occasions was $11 \%$.

Between 1993 and 1998, there were also four occasions when a successful break crop (beans, peas, or mustard) was grown in the continuously-cropped treatment (Table 7). On three of these occasions (in 1994 and 1997 at Leeds and in 1998 at Silsoe) the yield in the alternately-cropped treatment was significantly less $(\mathrm{P}<0.05)$ than that in the continuouslycropped treatment. Across the four occasions, the yield in the alternately-cropped treatment was $5 \%$ less than that in the continuously-cropped treatment.

On the three occasions when a cereal crop was grown after a break crop in the continuously-cropped treatment, the corresponding yield in the alternately-cropped treatment was once significantly higher (in 1996 at Cirencester) and twice significantly lower (in 1994 and 1998 at Leeds). 


\section{DISCUSSION}

\section{Choice of poplar hybrid}

The superior performance of Beaupré, an interamericana hybrid, relative to $P$. trichocarpa and euramericana hybrids, across each of the three sites in this trial, is similar to the response of Beaupré compared to $P$. trichocarpa and euramericana hybrids across nine sites in England, Scotland, and Wales reported by Tabbush and Beaton (1998). The fact that Beaupré has shown the greatest height and diameter across a range of sites suggests that it is generally well-adapted to most lowland environments in the UK. Milne et al. (1992) and Souch and Stephens (1998) have related the high growth rate of Beaupré, in comparison to Robusta and Trichobel, to the development of a larger leaf area and hence a capacity to intercept a higher proportion of radiation. Although this might be expected to cause a greater reduction in crop yields, during the seven years Beaupré did not show a greater effect on crop yields than the other three hybrids. This is probably a result of the pruning regime which maintained the canopy depth of each tree equal to approximately half of the tree height.

Because of the high growth rate, some farmers in the UK have recently planted monocultures of Beaupré. Although this may appear sensible based on timber production measurements alone, large blocks of a single hybrid can be particularly vulnerable to new strains of disease. At the end of 1997 and in 1998, the Beaupré trees at the Cirencester site were particularly affected by a new race of the leaf rust Melampsora larici-populina (Lonsdale and Tabbush, 1998) previously only reported in Continental Europe. This may explain, in part, the reduction in the annual diameter increment of the poplar in the continuously-fallow treatment at Cirencester from 34-36 mm between 1995 and 1997 to only $19 \mathrm{~mm}$ in 1998 (Table 6). Although in 1998, the cumulative growth of Beaupré was still superior to the other three hybrids, in order to minimise disease susceptibility Lonsdale and Tabbush (1998) recommend planting a mixture of cultivars of differing genetic origins.

\section{Timber formation}

The individual measurements of tree height for each hybrid in the fallow treatment at the end of 1998 (seven-years after planting) can be used to determine a value for the top height', which in turn can be used to predict the maximum mean annual increment of timber volume (yield class) for that stand. The 'top height' is the mean height of those hundred trees per hectare with the largest diameter at breast height (Hamilton, 1975), and therefore it ignores the heights of the smallest third of the trees at a density of 156 trees per hectare. Using the tables presented by Christie (1994) for a density equivalent to 156 trees per hectare, the predicted maximum mean annual increment for Beaupré within the continuously-fallow plots ranged from $14 \mathrm{~m}^{3} \mathrm{ha}^{-1} \mathrm{a}^{-1}$ at Leeds to $20 \mathrm{~m}^{3} \mathrm{ha}^{-1} \mathrm{a}^{-1}$ at Cirencester (Table 8).

However the above analysis ignores the fact that the trees at Leeds have a substantially larger diameter for a given height, than the trees at Cirencester and Silsoe (Table 8). An alternative method for comparing the relative productivity of the three sites is to calculate the cumulative timber production $\left(\mathrm{V} ; \mathrm{m}^{3} \mathrm{ha}^{-1}\right)$ from the number of trees $\left(N\right.$; trees ha $\left.{ }^{-1}\right)$, the mean height $(h ; \mathrm{m})$, the mean diameter at breast height $(d b h ; \mathrm{m})$ and a form factor $(f)$ (Philip, 1994) (Equation 1). 


$$
V=N h \pi\left(\frac{d b h}{2}\right)^{2} f
$$

Equation 1

Assuming 156 trees ha $^{-1}$ and a form factor for seven-year-old poplar of 37\% (Hamilton, 1975), and using the values for the mean height and diameter for Beaupré in the continuously-fallow treatment (Table 8), the estimated timber volume of the trees at Leeds is similar to those at Silsoe. These results show that it can be misleading to predict a yield class for widely-spaced poplar based on measurements of top height alone. The greater diameter growth per increment of height growth for poplar at Leeds, relative to Silsoe, is probably a result of the greater exposure of the site to wind (Table 1).

The predicted maximum mean annual increments of 14 to $20 \mathrm{~m}^{3} \mathrm{ha}^{-1}$ for Beaupré indicates the superior performance of this cultivar to the other three cultivars in the trial. Jobling (1990) reported maximum mean annual increments for traditional poplar cultivars, such as Robusta, as being in the range of 4 to $14 \mathrm{~m}^{3} \mathrm{ha}^{-1}$. Beaupré, growing on a sheltered valley site at Old Wolverton near Milton Keynes in Buckinghamshire, UK has been reported by Newman et al. (1995) as having an even greater maximum mean annual increment of $26 \mathrm{~m}^{3} \mathrm{ha}^{-1}$. Such differences in volume production indicates that careful site selection is critical if new poplar hybrids are to achieve the maximum mean annual increments of 22 to $28 \mathrm{~m}^{3} \mathrm{ha}^{-1}$ used in some financial analyses of silvoarable agroforestry (Willis et al., 1993).

Table 8. The predicted maximum mean annual increment in timber volume for Beaupré in the continuously-cropped treatment, based on the top height seven years after planting and an interpolation of Christie's (1994) provisional tables for poplar, at each of three lowland sites in England.

\begin{tabular}{|c|c|c|c|}
\hline \multirow[b]{2}{*}{ Characteristic } & \multicolumn{3}{|c|}{ Site } \\
\hline & Cirencester & Leeds & Silsoe \\
\hline Top height (m) & 13.7 & 11.8 & 13.1 \\
\hline Predicted maximum mean annual increment $\left(\mathrm{m}^{3} \mathrm{ha}^{-1} \mathrm{a}^{-1}\right)$ & 20 & 14 & 18 \\
\hline Height (m) & 13.0 & 11.6 & 12.7 \\
\hline Diameter at breast height (mm) & 212 & 218 & 203 \\
\hline Estimated timber volume at seven years ${ }^{1}\left(\mathrm{~m}^{3} \mathrm{ha}^{-1}\right)$ & 26 & 24 & 24 \\
\hline
\end{tabular}

${ }^{1}$ The estimated timber volume after seven years, is based on top height, diameter and a form factor of $37 \%$.

\section{Effect of the arable treatments on tree growth}

After seven years, the mean height and the diameter of the trees in the continuouslycropped treatment were respectively $10 \%$ and $21 \%$ less than those in the continuouslyfallow treatment (Table 3). Assuming a form factor of $37 \%$, the estimated marketable timber from the seven-year-old trees in the continuously-cropped treatment would be only $56 \%$ of that in the continuously-fallow treatment. This is similar to reductions in tree growth rates of $20-60 \%$ caused by competition with grass in a silvopastoral system (Campbell et al., 1994).

The principal cause of the lower tree growth rates in the continuously-cropped, compared to the continuously-fallow treatment, is likely to be competition for water and/or nutrients. In an investigation of the effects of a competing grass crop on the growth of apple trees, Hipps et al. (1990) reported that the availability of water was probably a more important limiting factor than nitrogen. Certainly an important role for water is supported 
by the observation that the effect of the arable treatment on height increment was particularly strong during the dry summer of 1995 (Table 5).

The possibility of significant competition between the trees and the crop for water was also indicated in a detailed study of the soil water content within an alternately-cropped treatment at Silsoe during 1995 (Burgess et al., 1996). Between 27 April and 3 August 1995, the decline in the soil water content within the cropped area of winter wheat and the uncultivated 2-m wide area at the base of a Beaupré hybrid (141-192 mm) was substantially more than the decline within the fallow area $(5-127 \mathrm{~mm})$. Souch (1996), comparing the responses of two-year-old poplar hybrids, reported that Beaupre showed a reduction in transpiration once the soil water potential reached $-43 \mathrm{kPa}$, and that each subsequent litre reduction in water use resulted in approximately $4.4 \mathrm{~kg}$ less total dry matter production. At the site at Silsoe, a soil water potential of $-43 \mathrm{kPa}$ is equivalent to a deficit of about $50 \mathrm{~mm}$ within the top metre of soil (Burgess et al., 1996). These results indicate that during a dry summer, the availability of water in the soil beneath an autumnsown crop is likely to be less than that within a fallow. The implication is therefore that this reduction is sufficient to cause a difference in the growth of recently-established trees.

The above results suggest that, during a dry summer, the water use of an arable crop could be sufficient to reduce the growth of recently-planted poplar, compared to the situation where the poplar was surrounded by a bare-earth fallow. This is despite the arable crop being cultivated at a distance of at least $1 \mathrm{~m}$ from the base of the trees and weed growth at the base of the trees being suppressed by a black plastic mulch.

\section{The effect of the experimental silvoarable system on crop yields}

The first effect of the experimental silvoarable system on crop yields is a direct reduction in the cropped area. The practical experience across the network sites was that the tree rows should have a minimum width of $2 \mathrm{~m}$ to minimise the risk of damage to the trees from agricultural machinery, and vice versa. Hence as the tree row spacing on the trial sites was $10 \mathrm{~m}$, it was only possible to crop $80 \%$ of the original area. Obviously, the proportion of the uncultivated land will decrease if the spacing between the trees is greater. In fact as most agricultural machinery in the UK is designed to work at widths of 12,18 or $24 \mathrm{~m}$, after allowing $2 \mathrm{~m}$ for the tree row, a spacing of 14, 20 or $26 \mathrm{~m}$, between tree rows is likely to be more appropriate than $10 \mathrm{~m}$ on commercial farms.

Across the three sites, in the presence of trees, the yield per unit cropped area, relative to the crop yield in the control areas, was an average of $4 \%$ less in the first three years and an average of $10 \%$ less between years four and six. These reductions are substantially less than decreases of 31,36 and $82 \%$ reported by Newman et al. (1995) for spring wheat and barley under three, five and six-year-old poplar respectively when planted at a particularly close spacing of $14 \mathrm{~m} \times 1 \mathrm{~m}$ and with a predicted yield class of 26 (i.e. the predicted maximum mean annual increment, if the spacing had been $8 \mathrm{~m} \times 8$ $\mathrm{m}$, would be $26 \mathrm{~m}^{3} \mathrm{ha}^{-1} \mathrm{a}^{-1}$ ). However they are comparable to a yield reduction of $9 \%$ reported for spring wheat below six-year-old poplar, also with a yield class of 26, at a spacing of $14 \mathrm{~m}$ x $6 \mathrm{~m}$ in Buckinghamshire, UK (Newman et al., 1995). The possible reasons for the effect of the trees on the yields in the continuously-cropped treatment include shading, competition for water (Foulkes et al., 1993), the ingress of weeds (Milsom et al., 1994), and slug damage (Griffiths et al., 1994). 
The potential effect of shading by the trees on the yield of an understorey crop ( $Y ; \mathrm{g}$ $\mathrm{m}^{-2}$ ), such as wheat, can be directly related to the incident short-wave solar radiation $(S$;

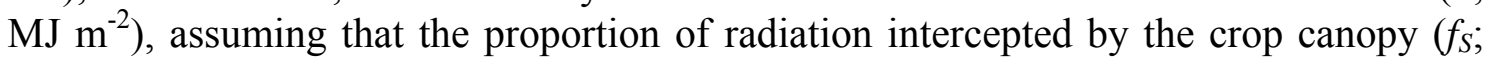
$\%)$, the ratio of total dry matter production to intercepted radiation $\left(\varepsilon_{S} ; \mathrm{g} \mathrm{MJ}^{-1}\right)$, and the harvest index $(H I)$ remain constant (Monteith, 1977) (Equation 2).

$$
Y=S \cdot f_{s} \cdot \varepsilon_{s} \cdot H I
$$

Using a more detailed model of the growth and development responses of winter wheat to radiation, Kocabas et al. (1993) indicated that a $20 \%$ reduction in radiation throughout the growing season would result in a $15 \%$ lower yield.

The tube-solarimeter measurements taken at Silsoe between April and July 1997, six-years after planting, indicated that the amount of short-wave radiation beneath the five-year-old trees was only $82 \%$ and $88 \%$ of that in the control treatment, at distances of $2.5 \mathrm{~m}$ and $4.5 \mathrm{~m}$ perpendicular to the tree row respectively. Such a reduction in radiation would appear sufficient to explain why the yields in the continuously-cropped treatment at Cirencester and Leeds were only $85 \%$ of those in the control treatment. In contrast the lack of an effect of trees on crop yield and the relatively low winter cereal yields at Silsoe $\left(5.4 \mathrm{tha}^{-1}\right)$ suggests that a factor or factors other than solar radiation were constraining yields at that site.

The influence of shade rather than competition for nutrients in constraining the yield of the arable crops, is also supported by the observation that the poplar had a greater effect on the yield of break crops than that of winter cereals. For example, between 1995 and 1998, the yield of the spring mustard and winter beans in the continuously-cropped treatment was only $79 \%$ of that in the control treatment. In contrast over the same time period, the yield of the winter cereals in the continuouslycropped treatment was $93 \%$ of that in the control (Table 7). Such an effect would be expected, as the spring mustard and the winter bean crops were planted and harvested later than the winter cereals. Hence the peak light requirement of such crops is likely to coincide with the period from July to October when the poplars intercept the most light.

\section{The alternately-cropped treatment}

On the eight occasions, when a cereal crop was preceded by another cereal crop in the continuously-cropped treatment, the mean crop yield in the alternately-cropped treatment was $11 \%$ greater than that in the continuously-cropped treatment. A similar increase of 12\% across five sites was also reported by Froment and Grylls (1992), when the yield from wheat, immediately following a bare fallow was compared to the yield of continuous wheat in the maritime temperate climate of Britain. Froment and Grylls (1992) related the high yields after the bare fallow to an increase in the soil mineral nitrogen content.

In contrast on three of the four occasions when a break crop was grown, the yield in the continuously-cropped treatment was greater than that in the alternately-cropped treatment. Overall, across the four occasions, the yield in the alternately-cropped treatment was 5\% lower than that in the continuously-cropped treatment. These results suggest that break crops gain minimal yield benefit from being preceded by a fallow rather than a cereal crop. A possible reason for the lower yield in the alternately-cropped treatment is that the trees had both taller and broader canopies than those in the continuously-cropped treatment (Table 4). 
Although the exact response depends on the crop combination, as discussed above, the individual yields per cropped area within the alternately-cropped treatment were between $80 \%$ and $120 \%$ of that from the continuously-cropped treatment (Table 7). However when the yields are expressed in terms of the total area, there is obviously a large reduction in yield because only $8 \mathrm{~m}$ out of every $20 \mathrm{~m}$ were sown to an arable crop; this is half the area within the continuously-cropped treatment. Therefore if the alternately-cropped treatment is to be used commercially, the economic costs of only planting a small proportion of the area, must be outweighed by increased returns from the trees or savings in management costs.

An important potential advantage for management of the alternately-cropped treatment is that the fallow alleys allow year-round access to the poplar trees for pruning. In contrast if all of the alleys are allocated to continuous autumn-sown crops, then in order to minimise damage to crops, pruning activities may be limited to August and September between the harvest of one crop and the cultivation for the next. These are amongst the busiest months on arable farms and the availability of labour for pruning is likely to be minimal unless specialist pruners are employed. Secondly in the 1960s and 1970s, Bryant and May used alternate-cropping because, as the poplar trees sometimes delayed the harvesting of one crop, it would still allow the sowing of the next season's crop. Although this effect may be apparent in the future as the trees grow, there has been no noticeable delay in the harvesting of the crops within the alleys during the first seven years.

\section{Conclusion}

The analysis of the first seven years of tree growth and crop yields reported in this paper provides an initial basis for comparing the productivity and profitability of this experimental silvoarable system with conventional arable cropping and poplar production practices (Burgess et al., 2000). Future work will investigate the tree-crop interactions beyond the first seven years and assess the most profitable combination of poplar and arable crop for a given site.

\section{ACKNOWLEDGEMENTS}

The UK Ministry of Agriculture, Fisheries and Food sponsored the research between 1992 and 1995 and in 1997. At Leeds, the assistance of Emma Pilgrim, Caroline Dufils and Pascal Henner with harvesting and field work under the supervision of Chris Wright is gratefully acknowledged. At Silsoe, we acknowledge the assistance of Neil Hutton, Ian Seymour and Bob Walker. We also wish to thank Karsten Bechtel for the collection and initial analysis of the light interception data. At Cirencester, the initial site planting and management and data collection was undertaken by Bob Evans.

\section{REFERENCES}

Beaton A (1987) Poplars and agroforestry. Quarterly Journal of Forestry 81: 225-233

Burgess PJ, Stephens W, Anderson G and Durston J (1996) Water use by a poplarwheat agroforestry system. Aspects of Applied Biology 44: 129-136

Burgess PJ, Seymour I, Incoll LD, Corry DT, Hart B and Beaton A (2000) The application of silvoarable agroforestry in the UK. Aspects of Applied Biology 62:269-276. 
Campbell CD, Atkinson D, Jarvis PG and Newbould P (1994) Effects of nitrogen fertilizer on tree/pasture competition during the establishment phase of a silvopastoral system. Annals of Applied Biology 124: 83-96

Christie JM (1994) Provisional Yield Tables for Poplar in Britain. Forestry Commission Technical Paper 6. Forestry Commission: Edinburgh, UK

Foulkes MJ, Sylvester-Bradley R, Scott RK and Ramsbottom JE (1993) A search for varietal traits that may influence performance of winter wheat during droughts in England. Aspects of Applied Biology 34: 279-288

Froment MA and Grylls JP (1992) Changes in soil mineral nitrogen during set-aside and effect of rotational fallows on the yield and N-optima of subsequent cereal crops. In: Clarke J (ed.), Set-aside pp. 23-28. British Crop Protection Council, Farnham, UK

Griffiths JG, Phillips DS, Wright C, Compton SG and Incoll LD (1994) Problems with slugs in a silvoarable agroforestry system. Agroforestry Forum 5(2): 24-26

Hamilton GJ (1975) Forest Mensuration. Forestry Commission Booklet 39. HMSO, London, UK.

Hipps NA, Ridout MS and Atkinson D (1990) Effects of alley sward width, irrigation and nitrogen fertiliser on growth and yield of Cox's Orange Pippin apple trees. Journal of the Science of Food and Agriculture 53: 159-168

Jobling J (1990) Poplars for Wood Production and Amenity. Forestry Commission Bulletin 92. HMSO: London, UK

Kocabas Z, Mitchell RAC, Craigon J and Perry JN (1993) Sensitivity analysis of the ARCWHEAT1 crop model: the effect of changes in radiation and temperature. Journal of Agricultural Science 120: 149-158

Lonsdale D and Tabbush P (1998) Poplar rust and its recent impact in Great Britain. Forestry Commission Information Note 7, Forestry Commission: Edinburgh, UK

Milne R, Sattin M, Dean JD, Jarvis PG and Cannell MGR (1992) The biomass production of three poplar clones in relation to intercepted solar radiation. Forest Ecology and Management 55: 1-14

Milsom TP, Turley D, Lane P, Wright B, Donaghy SJ and Moodie P (1994) Boundary strips in cereal fields: dynamics of flora, weed ingress and implications for crop yield under different strip management regimes. In: Boatman ND (ed.) Field Margins: Integrating Agriculture and Conservation BCPC Monograph 58, pp. 179-182. British Crop Protection Council: Farnham, UK

Monteith JL (1977) Climate and the efficiency of crop production in Britain. Philosophical Transactions of the Royal Society of London A 316: 245-259

Newman SM, Wainwright J, Hutton N, Wu Y, Marshall C, Amatya AM, Ranasinghe D MSHK and Morris RM (1995) Spacing and variety effects on poplar silvoarable systems in the UK. Agroforestry Forum 6(2): 37-43

Nix J (1997) Farm Management Pocketbook. University of London: Wye College, UK Philip MS (1994) Measuring Trees and Forests. CAB International: Wallingford, UK

Potter CJ, Nixon CJ and Gibbs JN (1990) The introduction of improved poplar clones from Belgium. Research Information Note, Vol. 181. Forestry Commission: Edinburgh, UK

Souch CA (1996) Water use and productivity in three poplar clones. Unpublished PhD thesis. Cranfield University, Silsoe, Bedfordshire, UK.

Souch CA and Stephens W (1998) Productivity and water use in three hybrid poplar clones. Tree Physiology 18: 829-835 
Tabbush P (1995) Approved poplar clones. Research Information Note, Vol. 265. Forestry Commission: Edinburgh, UK

Tabbush P and Beaton A (1998) Hybrid poplars: present status and potential in Britain. Forestry 71: 355-364

Willis RW, Thomas TH and van Slycken J (1993) Poplar agroforestry: a re-evaluation of its economic potential on arable land in the United Kingdom. Forest Ecology and Management 57: 85-97 